Branko Dijanošićl

\title{
FUNKCIONALNA PISMENOST POLAZNIKA OSNOVNOG OBRAZOVANJA ODRASLIH OD TREĆEG DO ŠESTOG OBRAZOVNOG RAZDOBLJA
}

\section{- Sažetak -}

Prema statističkim podacima iz popisa stanovništva 2001. godine, 2,88\% stanovnika starijih od 15 godina nije uopce polazilo dok njih 16,76\% nema završenu osnovnu školu, a najveći broj njih - 47,06\% ima završenu tek srednju školu. (Iako je u Hrvatskoj proveden popis stanovništva 2011. godine, još uvijek nisu obrađeni podaci kojima bismo se mogli poslužiti za uspoređivanje.) Podaci o stanju obrazovanja stanovništva (iz 2001. godine) upućuju da je razina pismenosti, odnosno funkcionalne pismenosti, vrlo niska. U ovom istraživanju provedeno je ispitivanje funkcionalne pismenosti polaznika osnovnog obrazovanja odraslih od trećeg do šestog obrazovnog razdoblja. Ispitivanje je provedeno prema metodologiji UNESCO-a, a za potrebe istraživanja prilagođen je IALS (International Adult Literacy Survey) - Međunarodni upitnik pismenosti odraslih, koji se koristi u međunarodnim istraživanjima. Ispitivana je prozna, dokumentacijska i računska funkcionalna pismenost u razinama 1 do 5, pri čemu razina 1 predstavlja elementarnu pismenost, a 5 ekspertnu pismenost. Ispitivanje se temeljilo na mjerenju vještina na zadacima i problemima iz realnoga života. U ispitivanju su korišteni grafikoni, upute na proizvodima, novinski članci, reklame, različiti simboli kao i jednostavni izračuni kojima se susrećemo svakodnevno. Analiza rezultata pokazuje da je razina funkcionalne pismenosti kod polaznika osnovnog obrazovanja odraslih niska, uglavnom na razini jedan idva, općenito nešto je malo bolja kod računske pismenosti. Rezultati se ne razlikuju od rezultata svjetskih istraživanja koja se rade za cijelu populaciju. Svjetska su istraživanja pokazala da je oko $70 \%$ cijele populacije unutar pojedine države funkcionalno nepismeno (Slovenija, koja je radila istraživanje 1998. godine, ima od 65 do 77 posto funkcionalno nepismenih), odnosno na ispitivanjima

1 Mr. Branko Dijanošić, Pučko otvoreno učilište Ludbreg, Hrvatska, branko.dijanosic@pou-ludbreg.hr. 
se postižu rezultati maksimalno prve i druge razine. Isti su rezultati dobiveni $i$ ovim istraživanjem, mada se ono mora smatrati preliminarnim, jer je prvi put kod nas upotrijebljen upitnik koncipiran tako kako to predviđa UNESCO, a osim toga radi se i o jednoj izdvojenoj populaciji u društvu (nemaju završenu osnovnu školu).

\section{Ključne riječi: pismenost, funkcionalna pismenost, prozna pismenost, dokumentacijska pismenost, računska pismenost, obrazovanje odraslih.}

\section{Uvod}

U vremenu u kojem sada živimo okruženi smo mnogobrojnim i raznovrsnim informacijama, stoga je pismenost vrlo značajna. Ona se ogleda u raznim formama: na papiru, kompjutoru, televiziji, mobilnim telefonima, jumbo plakatima, znakovima itd. Promatrajući pismenost u današnje vrijeme, dolazimo do novih spoznaja - uz elementarnu ili primarnu pismenost, tj. poznavanje čitanja, pisanja i računanja, kao osnovnih vještina, danas se upotrebljavaju i novi termini koje je nametnuo razvoj društvene zajednice i tehnologije. Novi termini u pismenosti su sekundarna ili funkcionalna pismenost (razumijevanje pisanih uputa u svakodnevnom životu, npr. upotreba pojedinih proizvoda, ispunjavanje ugovora ili formulara, razumijevanje društvenih kretanja i sl.) i tercijarna pismenost (koja obuhvaća nove tehnologije, informatiku, kompjutersku pismenost, Internet, SMS). Upravo je iz ovih dvaju posljednjih oblika pismenosti isključen velik broj ljudi. Funkcionalna (ne)pismenost nije samo problem nedovoljno razvijenih društava već se s tim pojmom (problemom) sve više susreću i visoko industrijski razvijena društva. Sustav školovanja često nedovoljno priprema učenike za ono što će ih čekati u budućnosti kad jednog dana prestanu ići u školu. Školstvo je u većini zemalja definirano trajanjem, a ne postignućima. Taj problem je vidljiv u zemljama Europske unije; npr., Njemačka ima sve većih problema budući da je program u osnovnim školama tako strukturiran da se sadržaji moraju obraditi, bez obzira savladali ga učenici ili ne. Ukoliko se ne obrade propisani sadržaji, roditelji djecu premještaju u drugu školu koja će odraditi propisani program bez obzira na krajnji rezultat. Slična je situacija i u našim školama. Tržište rada postalo je nemilosrdno tražeći veće kompetencije ili pak posebna specijalistička znanja radnika. Danas se rijetko mogu pronaći poslovi koji zahtijevaju samo elementarnu pismenost ili je uopće ne zahtijevaju. Globalizacijski procesi obuhvaćaju sve sfere ljudskog 
djelovanja i to bez obzira gdje se nalazili, i bez obzira prihvaćamo li te trendove ili ne. Razvoj novih tehnologija sve više mijenja upotrebu klasičnih oblika sve je manje knjiga, a sve više elektroničkih dokumenata, tako da osim znanja čitanja i pisanja moramo savladavati i nove tehnologije. Pismenost je postala jedno od najvažnijih sredstava za postizanje različitih osobnih ciljeva i za obavljanje raznih uloga: u školi, na radnom mjestu, u obitelji i u društvu, kako na lokalnoj tako i na globalnoj razini. Imamo li na umu činjenicu da se količina znanja u svijetu strelovito povećava, pismenost je od esencijalne važnosti za svakog pojedinca. Razina pismenosti utječe na nekoliko aspekata ljudskog života: stjecanje naobrazbe, mogućnost zaposlenja, uspješnost na radnom mjestu, samoostvarenje i uspješnost djelovanja u zajednici.

\section{Definiranje pojmova}

Za pravilno razumijevanje istraživanja pismenosti potrebno je definirati pojmove, da bi se izbjegli problemi oko interpretacije istraživanja. Naime, problemi mogu nastati u terminološkim nesuglasicama, kao i u različitim metodama mjerenja pismenosti koje mogu dati i različite rezultate. Poimanje i uloga pismenosti mijenjali su se tijekom povijesti, da bi u zadnjem desetljeću pod utjecajem razvoja informacijsko-komunikacijske tehnologije stekli i neke nove dimenzije. Nekada je pismenost, kao vještina, bila potrebna ljudima koji se školuju, otvarala im je put do stjecanja znanja, danas je zbog promijenjene organiziranosti društva potrebna svima.

Različiti autori različito promatraju pojam pismenosti i različito ga definiraju. Razumijevanje pojma pismenosti s obzirom na povijest možemo podijeliti na etape:

- do 1950. godine - podrazumijevala se alfabetska pismenost,

- iza 1950. godine govori se o funkcionalnoj pismenosti kao širem pojmu - biti pismen znači sporazumijevanje, tj. znati čitati, pisati, slušati i govoriti (Bešter, 2003).

Današnji pak pojam pismenosti u sebi uključuje i proces (funkcionalna pismenost je proces koji traje cijeli život).

Pitanje definiranja pojma pismenosti nije ni jednostavno ni lako. Definicije se mogu pronaći u različitim rječnicima, ali je kompleksnost pojma velika pa takve definicije uglavnom ne odgovaraju i realnom stanju. U novije vrijeme javlja se nevjerojatno mnogo različitih disciplina i interesa vezanih uz pojam pismenosti. Kako ističe Burton (2007; str. 6), ,javlja se prava eksplozija interesa za opisivanje pojma pismenosti. Istražuju se aspekti o kojima prije 
nekoliko godina nitko nije ni razmišljao, te je tako pojam pismenosti postao svojevrstan kôd za puno kompleksnije poglede od uobičajenih koje smo do sada podrazumijevali”.

UNESCO-ova preporuka (1978) vidi osnovnu pismenost i funkcionalnu pismenost kao etape rezultata procesa opismenjivanja. Prema toj preporuci, pismena je ona osoba koja može s razumijevanjem čitati i napisati kratku jednostavnu rečenicu koja se odnosi na njen svakodnevni život. Ovako široko postavljena definicija pismenosti odraz je zapadnog promišljanja u definiranju pojma pismenosti, jer podrazumijeva univerzalne kognitivne i tehničke vještine koje se mogu savladati bez obzira na pojedini specifični kontekst ili kulturno okruženje. Ursula Giere iz UNESCO-ovog instituta za obrazovanje upozorava da se „ni jedna definicija pismenosti i funkcionalne pismenosti ne upotrebljava jednoznačno u svim industrijskim zemljama te je stoga za potrebe istraživanja, praćenja i uspoređivanja potrebno problem sagledati u kontinuitetu razvoja društvenih odnosa i evolucije samog koncepta" (1987; str. 28). Iz navedenoga razloga, UNESCO predlaže slijedeće definicije koje će se moći primjenjivati u statističkom praćenju i usporedbi na međunarodnoj razini:

- osoba je pismena, ako može s razumijevanjem napisati i pročitati jednostavnu rečenicu o svom svakodnevnom životu,

- osoba je nepismena, ako nije u stanju napisati i pročitati jednostavnu rečenicu o svom svakodnevnom životu,

- osoba je funkcionalno pismena, ako se može uključiti u sve aktivnosti u kojima je potrebna pismenost za efikasno sudjelovanje u svojoj bližoj i daljoj okolini, te svojim sposobnostima čitanja, pisanja $\mathrm{i}$ računanja može doprinijeti osobnom boljitku i društvene zajednice u kojoj živi,

- osoba je funkcionalno nepismena, ukoliko se ne može uključiti u sve aktivnosti u kojima je potrebna pismenost za efikasno sudjelovanje u svojoj bližoj i daljoj okolini, te svojim sposobnostima čitanja, pisanja i računanja ne može doprinijeti osobnom boljitku i društvene zajednice u kojoj živi.

UNESCO je za potrebe istraživanja definirao područja ispitivanja funkcionalne pismenosti. To su:

- Prozna pismenost (Prose Literacy) - podrazumijeva znanje i vještine koje omogućavaju razumijevanje i korištenje informacija dobivenih iz tekstova, uključujući različite publikacije, priče, pjesme.

- Dokumentacijska pismenost (Document Literacy) - predstavlja 
znanje i vještine koje su neophodne da bi se locirale informacije koje se nalaze u različitim formularima, grafičkim prikazima, redovima vožnje, formularima za plaćanja, prijavnicama i sl.

- Računska pismenost (Numeracy Literacy) - podrazumijeva znanja i vještine neophodne za primjenu osnovnih računskih operacija (zbrajanje, oduzimanje, dijeljenje, množenje i postotni račun) kao pojedinačnih operacija ili pak složenijih operacija kao što su izvještaji o stanju na računu u banci, izračun kamata na kredite, određivanje poreza na vlastiti prihod i sl.

Ovakva podjela u funkcionalnoj pismenosti danas je uglavnom i podloga za ispitivanja $\mathrm{i}$ istraživanja, iako su se javila i druga istraživanja, osobito na polju funkcionalne informatičke pismenosti, kao i na polju medijske pismenosti (više o tome, Dijanošić, 2009).

\section{Rezultati istraživanja funkcionalne pismenosti}

Cilj ovoga istraživanja je utvrditi stanje funkcionalne pismenosti kod polaznika osnovnog obrazovanja odraslih i to od trećeg do šestog obrazovnog razdoblja, što odgovara polaznicima od 5. do 8. razreda osnovnog obrazovanja odraslih. Na temelju ovako određenog cilja utvrđeni se slijedeći zadaci istraživanja:

- utvrditi razinu funkcionalne pismenosti ispitanika prema metodologiji IALS (International Adult Literacy Survey) u tri područja - prozna, dokumentacijska i računska pismenost,

- ispitati razinu funkcionalne pismenosti s obzirom na broj završenih razreda osnovne škole,

- ispitati razinu funkcionalne pismenosti s obzirom na dob ispitanika,

- ispitati funkcionalnu pismenost s obzirom na spol,

- ispitati povezanost funkcionalne pismenosti i navike čitanja (novine, knjige, titlovi filmova),

- ispitati zavisnost funkcionalne pismenosti s obzirom na naviku pisanja (pisma, razglednice, zamolbe, SMS poruke).

Na temelju ovako definiranih zadataka istraživanja, opća hipoteza je glasila:

- Rezultati ispitivanja funkcionalne pismenosti polaznika osnovnog obrazovanja odraslih bit će niski (na prvoj i drugoj razini). 
Posebne hipoteze koje će u većoj mjeri omogućiti interpretaciju dobivenih rezultata istraživanja:

1. Rezultati testa funkcionalne pismenosti bit će na nižoj razini što je obrazovni nivo manji (manje završenih razreda osnovnog obrazovanja).

2. Rezultati ispitivanja bit će na nižoj razini što je dob ispitanika starija.

3. Rezultati ispitivanja bit će na nižoj razini kod ispitanika koji nemaju naviku čitanja novina, knjiga, titlova filmova, kao i kod onih koji se ne koriste pisanom komunikacijom (razglednice, zamolbe, pisma i dr.).

4. Rezultati ispitivanja neće utvrditi značajnu razliku u funkcionalnoj pismenosti prema spolu ispitanika.

Anonimnom anketom obuhvaćeno je 109 odraslih polaznika viših razreda osnovnog obrazovanja odraslih u gradovima: Ivanec, Karlovac, Osijek i Zagreb. Uzorak je dakle, prigodni, relativno mali. Broj polaznika osnovnog obrazovanja odraslih u Republici Hrvatskoj prema podacima iz Statističkog ljetopisa za 2009. godinu (str. 458) u školskoj godini 2007./08. bio je 304, od čega 235 muškarca i 69 žena, u šk. god 2008./09. bilo je 349 polaznika (str. 479), 2009./10. 268 (str. 470), a u šk. godini 2010./11. bilo je 268 polaznika. U odnosu na posljednje dostupne službene statističke podatke, istraživanjem je obuhvaćeno 40,67\% polaznika osnovnog obrazovanja odraslih.

Prosječna životna dob anketiranih polaznika je 28 godina i dosta varira (koeficijent varijacije je 44\%). Zanimljivo je da je prosječna dob anketiranih muškaraca 23,6 godina, a žena 32,7 godina. Preko polovinu anketiranih polazi osmi razred i njihova prosječna životna dob je 25 godina. Prosječna životna dob polaznika iz gradske sredine je 25,2 godine, iz prigradske sredine 27,1 godina, a iz seoske sredine 30,5 godina. Prevladavaju dva razloga doškolovanja odraslih (kod 80\% anketiranih): osobna želja nešto naučiti i profesionalni razlog (dobiti svjedodžbu i lakše se zaposliti).

Šest pitanja u upitniku odnose se na svakodnevne navike čitanja (novina, knjiga, priručnika i filmskih titlova) i pisanja (razglednica/čestitki, pisama, molbi, poruka). Iz njih je uočljiva elementarna razina pismenosti anketiranih osoba. Iz dobivenih rezultata uočavamo da je kratko komuniciranje putem SMS poruka najpopularnije. Koristi ga $3 / 4$ anketiranih, ostali oblici (nešto opširnijeg) komuniciranja su znatno manje zastupljeni. Tek svaki peti polaznik piše razglednice/čestitke. Slična je situacija i sa pisanjem pisama i molbi. Istraživanje pokazuje da postoji statistički značajna povezanost između spola i korištenja SMS poruka kao načina komuniciranja putem mobilnih uređaja $(\mathrm{p}=0,036), 58 \%$ su muškarci. 
Kod istraživanja funkcionalne pismenosti, polaznici osnovnog obrazovanja odraslih u ovoj anketi trebali su odgovoriti na 15 pitanja. Pet pitanja se odnosilo na proznu pismenost, pet na dokumentacijsku pismenost i pet na računsku pismenost. Svako naredno pitanje u svakoj od tih triju dimenzija pismenosti bilo je teže od prethodnog, tj. odnosilo se na višu razinu pismenosti (primjer pitanja nalazi se u dodatku. U Tabeli 1 su prikazani postignuti rezultati anketiranih polaznika, a na Grafikonu 1 oni su prikazani s tri poligona frekvencija.

Tabela 1. Postignuti rezultati u testiranju funkcionalne pismenosti odraslih učenika po pojedinim dimenzijama i po postignutim razinama $(N=109)$

\begin{tabular}{|c|c|c|c|}
\hline $\begin{array}{c}\text { Postignuta razina } \\
\text { funkc. pismenosti }\end{array}$ & $\begin{array}{c}\text { Prozna } \\
\text { pismenost }\end{array}$ & $\begin{array}{c}\text { Dokument. } \\
\text { pismenost }\end{array}$ & $\begin{array}{c}\text { Računska } \\
\text { pismenost }\end{array}$ \\
\hline 0 & 60 & 14 & 11 \\
\hline 1 & 21 & 61 & 53 \\
\hline 2 & 22 & 25 & 22 \\
\hline 3 & 5 & 6 & 21 \\
\hline 4 & 1 & 2 & 1 \\
\hline 5 & - & 1 & 1 \\
\hline Ukupno polaznika & 109 & 109 & 109 \\
\hline Aritmetička sredina & 0,77 & 1,30 & 1,55 \\
\hline Stand. devijacija & 0,987 & 0,898 & 1,004 \\
\hline Koefic. varijacije & $128 \%$ & $69 \%$ & $65 \%$ \\
\hline
\end{tabular}

Na osnovu tabele može se donijeti nekoliko zaključaka:

- Polaznici su postigli najlošije rezultate u proznoj pismenosti. Njih preko polovine nije uspjelo postići niti najnižu (prvu) razinu. Prosjek je ispod $1 \mathrm{i}$ iznosi 0,77 .

- Polaznici su postigli bolje rezultate u dokumentacijskoj pismenosti. Većina polaznika dostigla je tek prvu razinu dokumentacijske pismenosti. Stoga je i prosjek vrlo nizak, iznosi 1,30.

- Polaznici su postigli najbolje rezultate u računskoj pismenosti. Većina ih je i ovdje postigla tek prvu razinu računske pismenosti, ali ih je $i$ nešto više postiglo treću razinu te prosjek iznosi 1,55. 
- Polaznici jako variraju s obzirom na postignute rezultate funkcionalne pismenosti. Najviše variraju s obzirom na proznu pismenost jer je standardna devijacija veća od aritmetičke sredine tako da koeficijent varijacije iznosi vrlo visokih $128 \%$. Manju varijabilnost uočavamo kod dokumentacijske i računske pismenosti, premda su i one visoke (iznose 69\%, odnosno 65\%).

- Sve tri distribucije postignutih najviših rezultata funkcionalne pismenosti su jače desnostrano asimetrične budući da prevladavaju niski rezultati, dok se viši rezultati pojavljuju u vrlo malo slučajeva. Distribucija frekvencija kod prozne pismenosti ima oblik slova L, dok su distribucije frekvencija za dokumentacijsku i računsku pismenost zvonolike, jače desnostrano asimetrične i vrlo slične. Prevladavanje niskih rezultata kod sve tri distribucije može ukazivati na potrebu kreiranja upitnika koji će biti primjereniji znanju ispitivane skupine, osobito njihovoj proznoj pismenosti, ali bi se time izgubila mogućnost usporedbe rezultata na svjetskoj razini. Odnosno ne bismo primjenjivali testiranje funkcionalne pismenosti na način kako se to radi u međunarodnim istraživanjima.

- Postignuta je prosječna razina svih triju vrsti pismenosti od 1,21 uz standardnu devijaciju od 0,78 i koeficijent varijacije od 64\%. Najlošiji rezultat imaju tri polaznika bez i jednog riješenog zadatka u sve tri dimenzije pismenosti, a najbolji prosječni rezultat ima jedan polaznik s prosjekom od 4,33.

Grafikon 1. Postignuti rezultati u testiranju funkcionalne pismenosti odraslih učenika, prikazani s tri poligona frekvencija

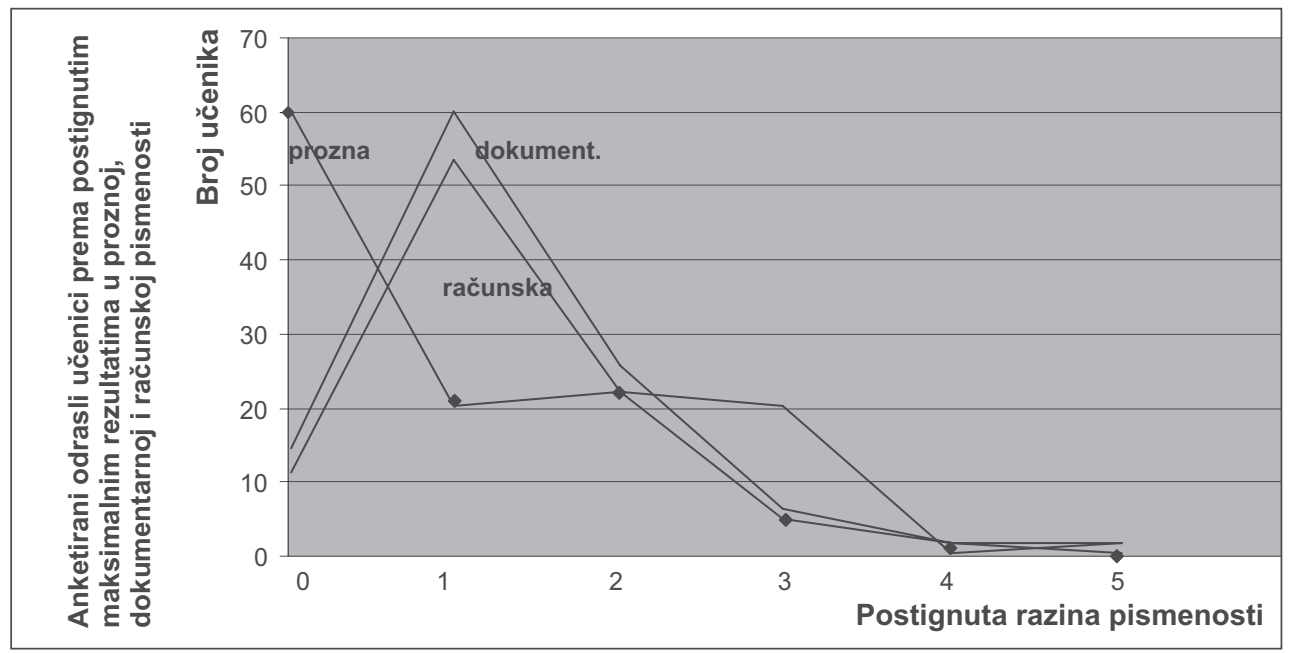


Istraživanjem je utvrđeno da ne postoji statistički značajna razlika u postignutoj razini prozne, dokumentacijske ili računske pismenosti kod polaznika koji su različitog spola, koji su u nižim u odnosu na one u višim razredima, koji su različitog bračnog statusa ili žive u različitim mjestima, gradskoj ili seoskoj sredini. Ovakav rezultat analize možda ne bi bio takav da je korišten veći uzorak ili slučajno izabrani uzorak. U tom pogledu bi ovo istraživanje funkcionalne pismenosti odraslih polaznika trebalo smatrati preliminarnim.

U istraživanju je izrađena i korelacijska analiza. U analizu su uključene sve kvantitativne varijable, njih šest, pa je svaka od njih stavljena u odnos sa svakom. Izračunati su Pearsonovi koeficijenti jednostavne linearne korelacije koji pokazuju slabu povezanost ili tek osrednju povezanost. S obzirom na smjer, pojavljuju se ne samo pozitivne nego i nekoliko negativnih korelacija.

Koeficijenti korelacije poredani od najjačeg prema slabijima su:

$\mathrm{r}=0,553$ - Između dokumentacijske i računske pismenosti korelacija je pozitivna, osrednja, najjača od svih koje su razmatrane. To znači da je polaznik s postignutom nižom razinom dokumentacijske pismenosti postigao u prosjeku i nižu razinu računske pismenosti, odnosno da je polaznik s postignutom višom razinom dokumentacijske pismenosti postigao u prosjeku i višu razinu računske pismenosti.

$\mathrm{r}=0,476$ - Između prozne i dokumentacijske pismenosti korelacija je pozitivna i osrednja. Znači da je polaznik s postignutom nižom razinom prozne pismenosti postigao u prosjeku i nižu razinu dokumentacijske pismenosti, odnosno da je polaznik $\mathrm{s}$ postignutom višom razinom prozne pismenosti postigao $\mathrm{u}$ prosjeku i višu razinu dokumentacijske pismenosti.

$\mathrm{r}=0,427$ - Između prozne i računske pismenosti korelacija je također pozitivna i osrednja. Znači da je polaznik s postignutom nižom razinom prozne pismenosti postigao u prosjeku i nižu razinu računske pismenosti, odnosno da je polaznik s postignutom višom razinom prozne pismenosti postigao u prosjeku i višu razinu računske pismenosti.

$\mathrm{r}=0,363$ - Između dokumentacijske pismenosti i broja čitanih/pisanih formi u svakodnevnom životu korelacija je pozitivna i slabija.

$\mathrm{r}=0,343$ - Između prozne pismenosti i broja čitanih/pisanih formi $u$ svakodnevnom životu korelacija je također pozitivna i slabija.

$\mathrm{r}=-0,233$ - Između dokumentacijske pismenosti i broja godina starosti korelacija je slaba i negativna. Znači da je polaznik s postignutom 
nižom razinom dokumentacijske pismenosti bio u prosjeku stariji dok je učenik s postignutom višom razinom dokumentacijske pismenosti bio u prosjeku mlađi.

$\mathrm{r}=0,224$ - Između računske pismenosti i broja čitanih/pisanih formi $\mathrm{u}$ svakodnevnom životu korelacija je pozitivna i slabija.

$\mathrm{r}=0,195$ - Između dokumentacijske pismenosti i razreda postoji pozitivna i slabija povezanost. Znači da je polaznik s postignutom nižom razinom dokumentacijske pismenosti bio u prosjeku $\mathrm{u}$ nižem razredu dok je učenik s postignutom višom razinom dokumentacijske pismenosti bio u prosjeku u višem razredu.

S obzirom na iznijete rezultate statističke obrade podataka, možemo reći da je opća hipoteza dokazana - razina funkcionalne pismenosti u tri promatrane kategorije je niska (1 i 2). Posebne hipoteze, koje su nam omogućile bolje sagledavanje uzorka nisu dokazane. $\mathrm{Na}$ razinu prozne, dokumentacijske i računske pismenosti ne utječe broj završenih razreda, dob polaznika kao ni navika čitanja i pisanja koju su ispitanici naveli u općem dijelu upitnika. Dokazana je samo hipoteza da spol ne utječe na rezultate istraživanja podjednako su funkcionalno nepismeni i muškarci i žene.

Iz iznesene interpretacije rezultata istraživanja, uz određena ograničenja $\mathrm{u}$ formiranju uzorka istraživanja, relativno malog broja ispitanih osoba (iako je u odnosu na dostupne službene statističke podatke ispitano 36\% populacije koja je bila upisana u osnovno obrazovanje odraslih u prethodnoj školskoj godini!), i uz činjenicu da je upitnik po metodologiji UNESCO-a prvi put primijenjen u jednom istraživanju kod nas, ipak je moguće dati određene zaključke i eventualno preporuke. Rezultati u ovom istraživanju pokazuju veliku povezanost $\mathrm{s}$ rezultatima iz drugih takvih istraživanja. Za primjer možemo uzeti Sloveniju, gdje se rezultati kreću od $65 \%$ do $77 \%$ osoba koje su postigle prve dvije razine pismenosti, u ovom istraživanju je to $67 \%$ kod prozne pismenosti, $77 \%$ kod dokumentacijske pismenosti i $68 \%$ kod računske pismenosti. Kod ove potonje, 19\% ispitanika postiglo je i treću razinu pismenosti. U ovom je trenutku nemoguće reći je li to rezultat životnoga iskustva polaznika jer ih svakodnevni život tjera da moraju dobro znati računati.

- Funkcionalna pismenost istraživane populacije je vrlo niska iako se u testiranju nalaze zadaci iz svakodnevnog života, a ne provjerava se školsko znanje. Pitanja koja se nameću: Kako funkcioniraju u svakodnevnom životu? Kako se snalaze u svojoj obitelji, na poslu ili pak društvenoj zajednici u kojoj žive? 
- Rezultati mogu ukazivati i na pitanje programa koji se provode u osnovnom obrazovanju odraslih. Koliko se, ustvari, polaznici pripremaju da nakon završenog obrazovanja steknu funkcionalna, a ne školska znanja, koja će im pomoći da se lakše nose sa složenim životnim pitanjima?

- Stječe se dojam da se tijekom školovanja dovoljno pažnje ne posvećuje kompetenciji „učiti kako učiti” u informalnom i neformalnom obrazovanju. Naime, zadaci su koncipirani tako da se na bazi životnog iskustva, dakle informalnog i neformalnog obrazovanja, relativno lako moglo odgovoriti na pitanje. Primjer procjena koliko ima goriva $u$ rezervoaru vozila je nešto $s$ čime se često srećemo $u$ realnom životu, dok je pak pitanje koliko ćemo banci platiti kamata na podignuti kredit nemoguća misija za anketirane polaznike.

- Program koji moraju savladati polaznici osnovnog obrazovanja odraslih je zastario gledano s pozicije funkcionalne pismenosti pojedinca koji mora biti osposobljen za aktivno sudjelovanje $\mathrm{u}$ društvu. Sadržaji nisu primjereni odrasloj populaciji, nema posebnih udžbenika koji bi poštovali osnovno pravilo da u obrazovanju odraslih koristimo pisani materijal koji je njima blizak i kreće od njihovih potreba. U njega nisu uključene ni nove kompetencije koje se postavljaju pred tu populaciju. Nužno je redefinirati obrazovne sadržaje ponuđene odrasloj populaciji koja se školuje ne samo da bi dobila svjedodžbu da je završila osnovno obrazovanje već da bi se mogla aktivno uključiti u društvo.

\section{Zaključna razmatranja}

$\mathrm{Na}$ kraju, može se konstatirati da je ovo preliminarno istraživanje. Ono je dalo očekivane rezultate $u$ ovako ograničenoj ispitivanoj populaciji. Rezultati se čak ni ne razlikuju od onih koji se postižu u velikim međunarodnim istraživanjima. U razvijenim zemljama koje su počele ranije provoditi takva istraživanja za svoju cijelu populaciju razvio se niz novih programa za suzbijanje funkcionalne nepismenosti. U sklopu Europske unije financira se i mnogo projekata pod nazivom druga šansa (Second Chance). Ovo istraživanje, kao i već spomenuto ranije istraživanje Bogdanovića i Matijevića (1990.) ukazuje na potrebu da se u Hrvatskoj pristupi jednom opsežnom istraživanju o stanju funkcionalne pismenosti u cijeloj populaciji. Rezultati takvog istraživanja bili bi od velike važnosti u kreiranju obrazovnih politika, strategija, školskih kurikula. Omogućila bi sagledavanje cjelokupnog problema i pomogla u postizanju cilja - društva koje uči. 


\section{Dodatak}

Primjer pitanja za dokumentacijsku pismenost na prvoj razini. Polaznik mora pronaći točan odgovor.

Dokumentacijska pismenost-1

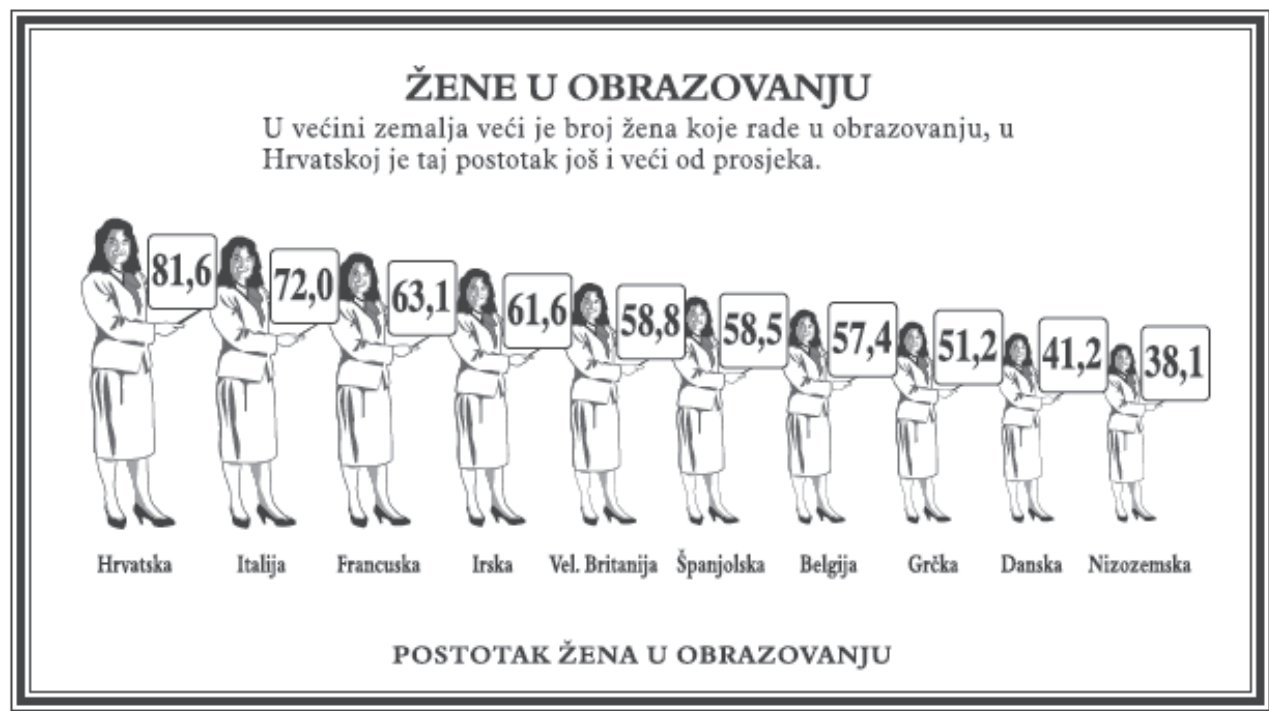

Pitanje:

1. Koliki je postotak žena koje rade u obrazovanju u Belgiji? 


\title{
FUNCTIONAL LITERACY OF PARTICIPANS IN ELEMENTARY ADULT EDUCATION FROM TIRTH TO SIGHSTS EDUCATIONAL CYCLES
}

\begin{abstract}
- Abstract -
According to the statistical data, in year 2001 in Croatia 2,88\% of inhabitants have not get any basic education and 16,76\% have not finished the basic education (primary school). Above this we have to add that 47,06\% of inhabitants have finished only secondary education. This is to conclude that inhabitants have very low level of the functional literacy. In this research functional literacy is tested according to the UNESCO standards. International Adult Literacy Survey was adopted for this purpose. Adults in Primary adult education from $5^{\text {th }}$ till $8^{\text {th }}$ grade were tested. According to the IALS, adults in primary education were tested in prose, documentary and numeracy literacy graded in levels from 1 (poor literacy) to 5 (expert literacy). The tasks were taken from everyday life different charts, symbols, simple calculation, and text from ads, newspaper or instructions for different products. The results show that the functional literacy is at the level 1 or 2 that indicates very poor level of Literacy. These results are comparable with the results from other researches which show us that 70\% of total population of the each state is functionally illiterate (Slovenia has conducted research in 1998 and the results for entire population were from 65 - 77\% illiterate on level 1 or 2). However, we have to take into consideration that this research is preliminary one because of the fact that this test is used for the first time and that tested population is a part of the entire society with one similarity - all of them have not finished primary education.
\end{abstract}

Key words: literacy, functional literacy, prose literacy, documentary literacy, numeracy literacy, adult education. 


\section{Literatura}

- $\quad$ Alibabić, Š. (1994), Funkcionalna pismenost i samoobrazovanje, Institut za pedagogiju i andragogiju Filozofskog fakulteta, Beograd.

- Andrilović, V., Matijević, M., Pastuović, N., Pongrac, S., Špan, M. (1985), Andragogija, Školska knjiga, Zagreb.

- Bešter, M. (2003), Funkcionalna (ne)pismenost v Sloveniji, Filozofski fakultet u Ljubljani, Ljubljana.

- Bogdanović, S. i Matijević, M. (1990), Nepismenost i ponovna nepismenost odraslih, Andragoški glasnik 36 (10-12), 311 - 328, Zagreb.

- Dijanošić, B. (2009), Prilozi definiranju pojmova funkcionalne pismenosti, Andragoški glasnik 22, 25-35, Zagreb.

- Giere, U. (1987), Functional illiteracy in industrialized countries: an analytical bibliography, UNESCO Institute for Education, Hamburg.

- Gradištar, A. (2000), Problemi pri pojmovanju in definiranju pismenosti, 4. andragoški kolokvij, 150-151, Ljubljana.

- Gruber, S. (2000), Modernizacija pomoću fleksibilnosti daljnjeg obrazovanja, U Gartenschlaeger, U., Hinzen, H., Perspektive i tendencije obrazovanja odraslih u Europi, izbor tekstova, Hrvatska zajednica pučkih i otvorenih učilišta, Zagreb.

- Hanžek i sur. (2001), Pismenost odraslih i sudjelovanje u obrazovanju, Andragoški institut Republike Slovenije, Ljubljana.

- Hladnik, M. (2007), Biti pismen danes, Didaktika, 9-11, Ljubljana.

- Kirsch, I. (2001). The international Adult Literacy Survey (IALS): Understanding What Was Measured, Research Publication Office, Princeton.

- Kranjc S., Marjanovič Umek, Lj., Nidorfer Šišković, M. (2000), Funkcionalna pismenost oseb, zaposlenih $v$ slovenski vojski, Obdobja, 24, 209-217, Ljubljana.

- Meek, M. (1992), On Being Literate, Heinemann Educational Books, Inc, Portsmourth.

- Medić, S. (1997), Nove tendencije i pristupi u istraživanju vaspitanja $i$ obrazovanja. U Medić, S. (Ur.), Istraživanja u pedagogiji i andragogiji, Institut za pedagogiju i andragogiju Filozofskog fakulteta Beograd, Beograd.

- Možina, E. (2001), Pismenost in udeležba odraslih v izobraževanju. Seminar školskega polja CEPS, $151-159$.

- Nash, R., The Three Kinds of Illiteracy. http://www.reformed.org/ webfiles/antithesis/index.html?mainframe=/webfiles/antithesis/v1n5/ ant v1n5 illiteracy.htm (5. 03. 2010).

- Petz, B. (2004). Osnove statistike za nematematičare, Naklada Slap, Jastrebarsko. 
- Samolovčev, B. (1977). Problem funkcionalizacije osnovnog obrazovanja odraslih, Andragoški glasnik, sv. 25, str. 21-25, Zagreb.

- (2003). Skills for the World of Tomorrow. Programme for International Student Assessment - PISA, OECD and UNESCO Institute for Statistics, Pariz.

- $\quad$ (2009 -2011). Statistički ljetopis, Državni zavod za statistiku, Zagreb.

- Velikonja, M., (Ur.) (2000), Pismenost, participacija i družba znanja, Andragoški institut Republike Slovenije, Ljubljana.

- Vlada Republike Hrvatske (2004), Akcijski plan provedbe strategije obrazovanja odraslih. Vlada Republike Hrvatske, Zagreb.

- http://www.unesco.org/new/en/education/themes/education-buildingblocks/literacy/ (15.06.2010).

- http://www.hcd.hr/datoteke/Zagreb_Conference_Proceedings.pdf (Literacy without Boundaries) - (15.10.2010).

- http://www.literacy.org/publications/functional-literacy-older-adults-casenetherlands (12.10.2010).

- http://www.statcan.gc.ca/pub/11f0019m/11f0019m2006275-eng.pdf (The Importance of Functional Literacy: Reading and Math Skills and Labour Market Outcomes.

- of High School Drop-outs by Ross Finnie and Ronald Meng, (20.04.2010). 